\title{
A Holistic Approach in Enhancing the Livestock Production in Drought-hit Watersheds: Case Studies of Ananthapuramu and YSR Kadapa Districts of Andhra Pradesh, India
}

\author{
P. V. R. M. Reddy, B. V. Ramana Kumar, R. Jhansi Rani* and Pullanna Vidyapogu \\ Remote Sensing Instruments, Plot No.7, Type-I, Industrial Estate, Kukatpally, \\ Hyderabad, India \\ *Corresponding author
}

Keywords

Livestock

Production, Holistic

Approach,

Institutional

Development,

Fodder

Development and

Rainfed Agriculture

Article Info

Accepted:

22 April 2021

Available Online:

10 May 2021

\section{A B S T R A C T}

Development of livestock production is very well connected with the watershed development activities. These are intended to equip production for the prioritized proportion of population in the drought-hit watershed villages. This is providing alternative and additional income opportunities and also created employment opportunities through mixed livestock and crop production technology. Enhancement of livestock production through watershed activities attained by a holistic approach which was addressed not only productivity-based activities but also other allied activities. Institutional systems with people's participation played a key role in meeting the main objectives of the watershed programme in general and livestock development in particular. This has become a promising tool to achieve unprecedented problems like unemployment and livelihoods development through asset creation especially in drought prone districts like Ananthapuramu and YSR Kadapa.

\section{Introduction}

The guiding principles of watershed development projects are basically focused on improving the areas of equity and gender sensitivity, decentralization, facilitating agencies, centrality of community participation, capacity building and technology inputs, monitoring, evaluation and learning, and organizational restructuring with institutional arrangements from central government to state and district level nodal agencies (National Rainfed Area Authority 2011). Policy interventions of watershed programme has been focusing from landbased activities to livelihoods developmental activities in addressing not only natural resource management to people's socioeconomic status. For this, phase-wise integrated approaches in soil and water 
conservation, production improvement systems, and livelihoods development have resulted in more productive through effective implementation. Livestock development is one of the main objectives of watershed development programme. This was evident in the supportive activities of livestock production such as fodder development, milk production, animal breeding and health camps. But the challenge in the drought prone areas like Ananthapuramu and YSR Kadapa districts of Andhra Pradesh is to enhance integrated farming systems through soil and water conservation which will help to improve livestock production with optimum level of water availability and soil moisture. All the watershed programme activities through holistic approach have assured in enhancing agriculture productivity, increase in individual income, and livelihood security in sustainable manner.

IWMP has taken Livestock production on priority based in order to improve rural livelihoods in inter-connecting the gaps between irrigation through increase of cropping intensity and quality of fodder and forage resources (Arya, et al., 2011). Water resource development and conservation seen as a crucial element for livestock production in the drought hit regions (Palsaniya, et al., 2012).

Awareness programmes about livestock production and health emphasized adequate training needed for quality of feed and fodder to the livestock at the line departments like department of animal husbandry, project implementing agency, non-government organizations, and networking of gopala mitra's at the cluster level (Gregersen, et al., 2007). Effective implementation of watershed activities with trained persons resulted to improve the breed, animal insemination, fodder development and milk production (Pathak, et al., 2013). Sustenance of Livestock production in watershed villages is not only dependent on organizational set up of watershed activities but the impacts of livestock production activities have to be maintained even after the project period (Puskur, et al., 2004).

Watershed programme has been given utmost important to improve the livestock and allied areas of activities in Batch-III projects of Ananthapuramuamu and YSR Kadapa districts in Andhra Pradesh. Analysis of the report on the importance of livestock in the watershed villages highlighted at various activities carried out in the livestock sector which have contributed to an increase in the animal population and provided income for poor, marginal and landless families in watershed project villages.

The study emphasized on mainly two aspects such as understanding the different livestock activities carried out under the watershed system and their effect on the socio-economic status of the watershed population. Also understanding various strategies and interventions in order to develop in the livestock production which have contributed to the holistic development of rural areas.

\section{Materials and Methods}

Qualitative and quantitative methods are used for the study. The study has conducted extensive field study and also gathered data from secondary sources. Qualitative analysis of the study was drawn from the field-based interviews from the key respondents and Quantitative analysis have drawn from the household surveys, P O Schedule, and focused group discussions.

Secondary data collected from the DWMA, Ananthapuramu and YSR Kadapa for BatchIII projects on different PSI activities and expenditure. 
Primary data collected from the beneficiaries of the watershed villages through household survey.

Household schedule collected on the socioeconomic, demographic and other aspects of the sample households.

PO schedule collected the information on the present status of infrastructure and other facilities available in the area.

Checklist for FGDs prepared and used extensively with the potential respondents.

The entire methodology adopted for sampling is schematically followed. A multistage sampling procedure was adopted for impact assessment of Batch-III projects covering all the watersheds in the districts.

In each project, micro-watersheds have considered as a unit to have a good representative nature of works undertaken both in physical and social aspects. After this, all the villages located in each microwatershed are considered to draw on the household sample for collecting socioeconomic data. FGDs (Focus Group Discussions) were organized in each village wherever the villages are less than six. In cases where the villages are more than six the villages are grouped and FGDs were organized for a cluster of 2 to 4 villages. Five percent of households are selected for survey, subject to a minimum of 75 households per project. The data collected from households is compared against the baseline data collected for drawing inferences.

\section{Data Analysis and Tabulation}

Livestock and related data analyzed from Ananthapuramuamu and YSR Kadapa districts of Batch III projects. The details of the data are pertaining to animal population and milk production in terms of pre-and post-implementation of watershed projects. Along with this, Focus Group Discussions (FGDs) were conducted and analyzed the impact of the watershed project on livestock development.

Livestock activities for Batch-III A total of 2 districts covered 38 projects and 164 MWS villages were analyzed.

The 2 districts livestock activities expenditure tabulated and analyzed in connection with the targets and achievement of budget released from the watershed programme as well as MGNREGS under the livestock development.

Analysis of data pertaining to animal population and milk production in terms of pre- and post-implementation of watershed projects.

Focus Group Discussions were conducted and analyzed about the impact of watershed project on livestock development.

\section{Study Area}

The livestock thematic study was conducted in Batch-III projects in the districts of Ananthapuramu and YSR Kadapa. A total of 2 districts covered 38 projects and 164 MWS villages. The livestock activities expenditure captured and analyzed for the batch-III projects of 2 districts especially on cattle population and milk production in pre and post implementation of watershed project. The table-1 explains about the study area details of batch-III projects of 2 districts. In Ananthapuramu, the total number of projects comprised as 29 in 29 mandals and the total project area is 2,18,658 ha. from the sanctioned extent area of the project $1,24,506$ ha. with the sanctioned cost of Rs. 14,940.72 (lakhs). In these, 188 MWS 
villages are included in the project. In YSR Kadapa, the total number of projects comprised as 9 in 9 mandals and in these, 38 MWS villages are included in the project. The total project area is $66,522 \mathrm{ha}$. from the sanctioned extent area of the project 39,890 ha. with the sanctioned cost of Rs. 4,786.80 (lakhs).

\section{Institutional Development}

Initiatives of watershed development programs have strengthened through institutional development systems in different kinds. These are helped in effective implementation of watershed activities based on the priority. This also improved democratic processes of collective action and participation by involving all the stakeholders in watershed development activities. Institutional arrangements placed at central level Ministry of Rural Development, state level by SLNA, DWMA at district level, gram sabha, village watershed committee, and self-help groups at the cluster level.

Livestock Development Activities in the Watershed Projects of Ananthapuramu and Ysr Kadapa Districts

Watershed programme focused on productivity enhancement and livelihoods priority-based activities along with conservation measures. Resource development and usage has planned to promote farming and allied activities and also promoted local livelihoods while ensuring resource conservation and regeneration of natural resources. The new approach systematically integrated livestock management as a central intervention and encouraged dairying. In the rainfed areas, the animal resources became a major source of income for the people. This was considered and effectively integrated as part of the watershed development projects. A comprehensive animal husbandry component has been contributed significantly to ensure better and sustainable livelihoods for the people in the rainfed areas. Accordingly, watershed programme promoted activities such as raising fodder, pasture development, sericulture, bee keeping, back yard poultry, small ruminants, other livestock, and microenterprises. Also, measures have taken up in order to improve the livestock through veterinary services.

\section{Convergence of MGNREGS - Livestock Development}

The IWMP programme convergence with various line departments in the rural development sector where MGNREGS played a key role in promoting employment guarantee to the rural community. It is implemented various works related to watershed programme especially NRM based activities. In the implementation level, sharing of funds \& staff between both the programmes of IWMP and MGNREGS are based on the type of projects executed at ground water recharge, drainage line treatment, afforestation, common property resources projects and others like flood control, roads, land development, fodder development and dry land horticulture.

\section{Fodder Development}

Fodder development is one of the crucial elements of the livestock production. Watershed development programme has been addressed this through interlinking or supportive systems of economic activities. To improve economic situation of people in the watershed villages especially in drought hit regions livestock production seen as an alternative income generation activity. For this allied activity of livestock development also given priority and involved people facilitating financial and technological 
assistance. The table- 2 contained the details of EGS activities among four districts of Rayalaseema region with sanctioned and executed works. It shows the total expenditure spent during the program was Rs. 49.3 (lakhs). Among these, Rs. 32.58 (lakhs), a major has spent in YSR Kadapa followed by Rs. 16.72 (lakhs) in YSR Kadapa district. The table-3 and figure- 1 explain the details of fodder development of works from the 2 districts of Rayalaseema region from Batch III. Fodder production activities have barren carried out in the watershed area by increasing green pasture species in barren lands as well as common lands. In this, it showed the fodder (qts) availability from pre-project status to post project with the end result. Ananthapuramu district shows that the highest increase in fodder availability as high as $11.6 \%$, preceded by YSR Kadapa district with $65.6 \%$ from 1,009 (qtls) with pre- project to 1,671 (qtls) in post project. The availability of the green fodder increased due to the watershed intervention activities when compared with the pre project period. The green fodder cultivation increased in waste lands in the watershed project area. The details of dairy cattle from pre to post IWMP-Watershed Project in Rayalaseema districts are furnished in Table and Fig-3.

\section{Milch Animals}

Milch animals and milk production is one of the important objectives of the watershed programe. This activity is intended to improve the socio-economic status of people by facilitating financial and other supportive systems assistance. It is not only seen as a productivity-based activity but also an income generating activity in providing employment to the poor and marginal sections of the society. This has been resulted in not only improving the milk production and animal breeding but also providing livelihoods security to the people.
In this, it showed the number of milch cattle from pre-project status to post project with the end result. YSR Kadapa district shows that $41.7 \%$ from 5,545 with pre-project to 7,857 in post project. Subsequently, Ananthapuramu district shows that $14.5 \%$ increase in cattle population from 21,816 to 24,978 . The cattle population has been increased due to the intervention of watershed activities to enhance the livestock development activities such as animal health camps, supply of breeding rams, fertility camps, small ruminant health camps, feed supply to pregnant milch animals during last 100 days of pregnancy, feed supply to AI born true to type calves, supply of breeding bucks, establishment of travices and also cattle troughs, cultivation of green fodder. As a result of these activities milk production has been increased gradually. The table- 4 indicates regarding the status of milk production pre and post project of watershed in batch-III projects of 2 districts.

\section{Milk Production}

The table-5 and fig-3 explain the details of milk production from the two districts of Rayalaseema region from Batch III. In this, it showed the number of milk production (kilolitre/year) from pre-project to post project period. Among these, the highest was in YSR Kadapa district with $172.7 \%$ from 5,191 to 14,153 . It is also reported that 14.5 $\%$ in Ananthapuramu milk production has been increased from 53,580 to 61,359 at end of the project due to the intervention of watershed activities. Production support improvements also one of the interventions enhanced the livestock development in the watershed programme. Therefore, many activities have been carried under the PSI which helped the increase of animal population and reduced mortality among the animals and increased dairy production. The table-7 explains district wise Productive 
Support improvement activities undertaken for the livestock development in the project area.

\section{PSI Activities}

PSI activities have also undertaken as supportive systems of livestock production such as breeding of animals, animal health coverage, and infrastructure development especially in providing farm implements.

A perusal of table- 6 explains the details of PSI activities undertaken in Ananthapuramu district of Batch - III. The main activities contained in the table are animal husbandry, CMSA activities, agricultural activities, fisheries, horticulture, and other line departments with the total physical works undertaken during the project period. The total number of physical works was 15,096 comprising of 433 animal husbandry, 482 CMSA activities, 11,111 agricultural activities, fisheries 5, horticulture 3,547 and other line departments constitute 3,552 physical works. Similarly for Y.S.R Kadapa are also presented in table 7 which provides information on the details of PSI activities undertaken in Batch - III. The main activities included are health coverage, nutritional support, breed development, infrastructure development, CMSA activities, agricultural activities, and horticulture with the total physical works undertaken during the project period. The total number of physical works was 8,457. Details of the above- mentioned activities in the table comprised as 684 for health coverage, works for nutritional support 684, for breed development 952, 4 for infrastructure development, 46 works for CMSA activities, 4,405 works for agricultural activities, and 2,350 works for horticulture.

\section{Results and Discussion}

The livestock sector plays a significant role in India's socio-economic growth. Not only does it provide nutritious healthy food for millions of people, it also creates substantial employment in both the rural and urban sectors. The sector also has the ability to create self- employment. Employment is one of the main indicators for watershed growth and its effect on alleviation of rural poverty.

Total employment has risen among the beneficiary households. The trend of employment changes towards horticultural crops and other commercial crops, along with non-farm activities that have increased significantly. The overall increase in income and consumption rates reflects the ability of watershed growth to enhance additional income sources such as livestock in watershed projects villages of Rayaseema district. Improvements in fodder development and common land have tremendous potential in creating employment generation for the rural population within their own villages.

Table.1 Study Area for the livestock thematic study

\begin{tabular}{|c|c|c|}
\hline Name of District & Ananthapuramu & YSR Kadapa \\
\hline No. of Projects & 29 & $\mathbf{9}$ \\
\hline No of Micro watersheds & 126 & $\mathbf{3 8}$ \\
\hline Project Area (Ha.) & 218,658 & $\mathbf{6 6 , 5 2 2}$ \\
\hline Sanctioned Area (Ha.) & 124,506 & $\mathbf{3 9 , 8 9 0}$ \\
\hline Sanctioned Cost (Rs. in Lakh) & $14,940.72$ & $\mathbf{4 , 7 8 6 . 8 0}$ \\
\hline No. of Blocks/ Mandals & 29 & $\mathbf{9}$ \\
\hline Name of Villages included in the & $\mathbf{1 8 8}$ & $\mathbf{3 8}$ \\
\hline Proiect & & \\
\hline
\end{tabular}


Table.2 Details of EGS activities for the fodder development

\begin{tabular}{|c|c|c|}
\hline S. No & District & Expenditure (Rs in Lakhs) \\
\hline 1 & Ananthapuramu & $\mathbf{1 6 . 7 2}$ \\
\hline 2 & YSR Kadapa & $\mathbf{3 2 . 5 8}$ \\
\hline & Grand Total & $\mathbf{4 9 . 3}$ \\
\hline
\end{tabular}

Table.3 Details of Fodder Development (Qt) Batch-III projects Pre and Post Watershed Project

\begin{tabular}{|c|c|c|c|c|}
\hline S. No & Name of the & Pre & Post project & Results \\
\hline $\mathbf{1}$ & Ananthapur & 7,854 & 8,768 & $\begin{array}{l}\text { Fodder production is } \\
\text { increased by 11.6\% }\end{array}$ \\
\hline $\mathbf{2}$ & YSR Kadapa & $\mathbf{1 , 0 0 9}$ & $\mathbf{1 , 6 7 1}$ & $\begin{array}{c}\text { Fodder production is } \\
\text { increased by 65.6\% }\end{array}$ \\
\hline
\end{tabular}

Table.4 Details of milch cattle (number) in Batch-III projects of Ananthapuramu and YSR Kadapa Districts

\begin{tabular}{|c|c|c|c|c|}
\hline S.No & Name of the Districts & Pre project & Post project & Results \\
\hline $\mathbf{1}$ & Ananthapuramu & 21,816 & 24,978 & $\begin{array}{c}\text { The milch animals are } \\
\text { increased by 14.5\% }\end{array}$ \\
\hline $\mathbf{2}$ & YSR Kadapa & $\mathbf{5 , 5 4 5}$ & $\mathbf{7 , 8 5 7}$ & $\begin{array}{c}\text { The milch animals are } \\
\text { increased by 41.7\% }\end{array}$ \\
\hline
\end{tabular}

Table.5 Milk Production: Kilo litr/Yr

\begin{tabular}{|c|c|c|c|c|}
\hline S. No & Name of dist & Pre project & Post & Results \\
\hline 1 & Ananthapur & 53,580 & 61,359 & $\begin{array}{l}\text { The milk production is } \\
\text { increased by } 14.5 \%\end{array}$ \\
\hline 2 & YSR Kadapa & 5,191 & 14,153 & $\begin{array}{l}\text { The milk production is } \\
\text { increased by } 172.7 \%\end{array}$ \\
\hline
\end{tabular}

Fig.1 Details of Fodder Development (Qt) Batch-III projects Pre and Post watershed project

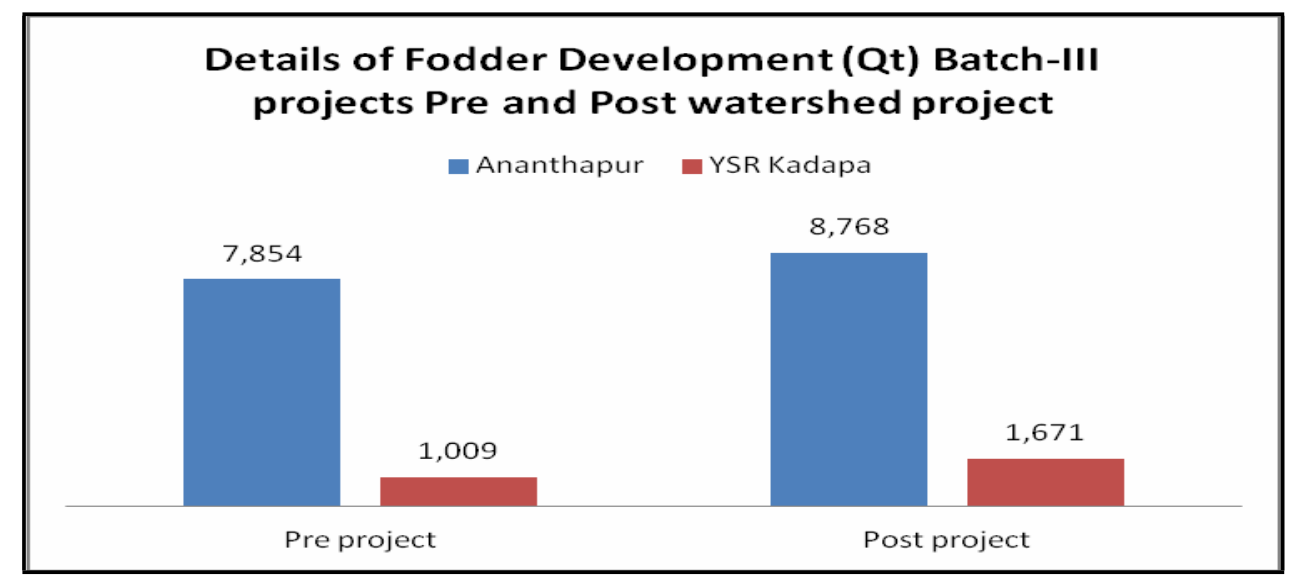


Table.6 PSI activities - Ananthapuramu district-Batch-III

\begin{tabular}{|c|c|c|c|}
\hline S. No. & Activity Name & Units & Total Physical \\
\hline 1 & Breed Development & & \\
\hline $\mathbf{a}$ & Supply of Breeding Rams & Nos & 433 \\
\hline 2 & CMSA activities & & \\
\hline $\mathbf{a}$ & Custom Hiring Center (CMSA) & Nos & 482 \\
\hline b & Farm Implements individual & Nos & 9321 \\
\hline $\mathbf{c}$ & Custom Hiring Centers (CHC) & Nos & 5 \\
\hline d & Individual High-cost Machinery & Nos & 107 \\
\hline $\mathbf{e}$ & Sprinkler Irrigation System & Nos & 309 \\
\hline $\mathbf{f}$ & Water Carrying Pipes & Nos & 884 \\
\hline $\mathbf{g}$ & $\begin{array}{c}\text { Sub Total (Agriculture Department } \\
\text { convergence) }\end{array}$ & & 10629 \\
\hline $\mathbf{h}$ & $\begin{array}{l}\text { Sub Total (Agriculture Activities } \\
\text { (PSI)) }\end{array}$ & & 11111 \\
\hline 3 & Others Line Dept Activities & & \\
\hline $\mathbf{a}$ & Supply of Nets & Nos & 5 \\
\hline b & Sub Total (Fisheries Department) & & 5 \\
\hline c & Tarphalin Sheets & Nos & 3531 \\
\hline d & Silpalins (60x40 with 120guage) & Nos & 16 \\
\hline $\mathbf{e}$ & Sub Total (Horticulture) & & 3547 \\
\hline $\mathbf{f}$ & $\begin{array}{c}\text { Sub Total (Others Line Dept } \\
\text { Activities) }\end{array}$ & & 3552 \\
\hline & Grand Total & & 15,096 \\
\hline
\end{tabular}

Fig.2 Details of milch cattle population in Batch-III projects of 2 districts

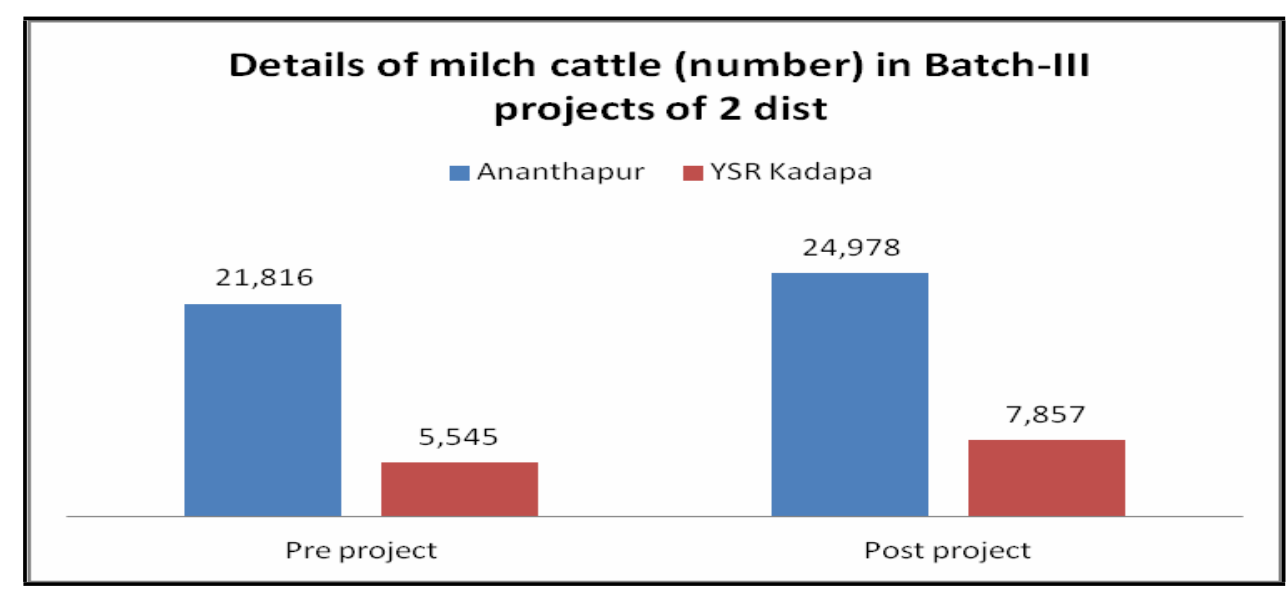


Table.7 PSI activities - YSR Kadapa district-Batch-III

\begin{tabular}{|c|c|c|c|}
\hline S. No. & Activity Name & Units & Total Physical \\
\hline 1 & Animal Husbandry Coverage & & \\
\hline 2 & Health coverage & & \\
\hline 3 & Animal Health Camps & Nos & 24 \\
\hline 4 & Fertility Camps & Nos & 18 \\
\hline 5 & Ruminant Health camps & Nos & 62 \\
\hline 6 & Sub Total (Health coverage) & & 684 \\
\hline 7 & $\begin{array}{l}\text { Feed Supply to Pregnant Milch } \\
\text { Animals during last } 100 \\
\text { days of pregnancy }\end{array}$ & Nos & 684 \\
\hline 8 & $\begin{array}{l}\text { Feed Supply to AI born true to type } \\
\text { calves }\end{array}$ & & \\
\hline 9 & Sub Total (Nutritional Support) & & 684 \\
\hline 10 & Supply of Breeding Rams & Nos & 848 \\
\hline 11 & Supply of Breeding Bucks & Nos & 104 \\
\hline 12 & Sub Total (Breed Development) & & 952 \\
\hline 13 & Establishment of Travices & Nos & 4 \\
\hline 14 & Sub Total (Infrastructure & & 4 \\
\hline 15 & $\begin{array}{l}\text { Sub Total (Animal Husbandry } \\
\text { Coverage) }\end{array}$ & & 1702 \\
\hline 16 & Custom Hiring Center (CMSA) & Nos & 46 \\
\hline 17 & Sub Total (CMSA activities) & & 46 \\
\hline 18 & Agriculture Department convergence & & \\
\hline 19 & Farm Implements individual & Nos & 1507 \\
\hline 20 & Custom Hiring Centers (CHC) & Nos & 1 \\
\hline 21 & Individual High cost Machinery & Nos & 20 \\
\hline 22 & Sprinkler Irrigation System & Nos & 4 \\
\hline 23 & Water Carrying Pipes & Nos & 2577 \\
\hline 24 & Supply of Zinc Sulphat & $\mathrm{Ha}$ & 250 \\
\hline 25 & $\begin{array}{c}\text { Sub Total (Agriculture Department } \\
\text { convergence) }\end{array}$ & & 4359 \\
\hline 26 & Sub Total (Agriculture Activities (PSI & & 4405 \\
\hline 27 & Fisheries Department & & \\
\hline 28 & Tarphalin Sheets & Nos & 2350 \\
\hline 29 & Sub Total (Horticulture) & & 2350 \\
\hline \multirow[t]{2}{*}{30} & $\begin{array}{l}\text { Sub Total (Others Line Dept } \\
\text { Activities) }\end{array}$ & & 2350 \\
\hline & Grand Total & & 8457 \\
\hline
\end{tabular}


Fig.3 Milk Production (Kilo litr/Yr) -Pre and Post watershed project

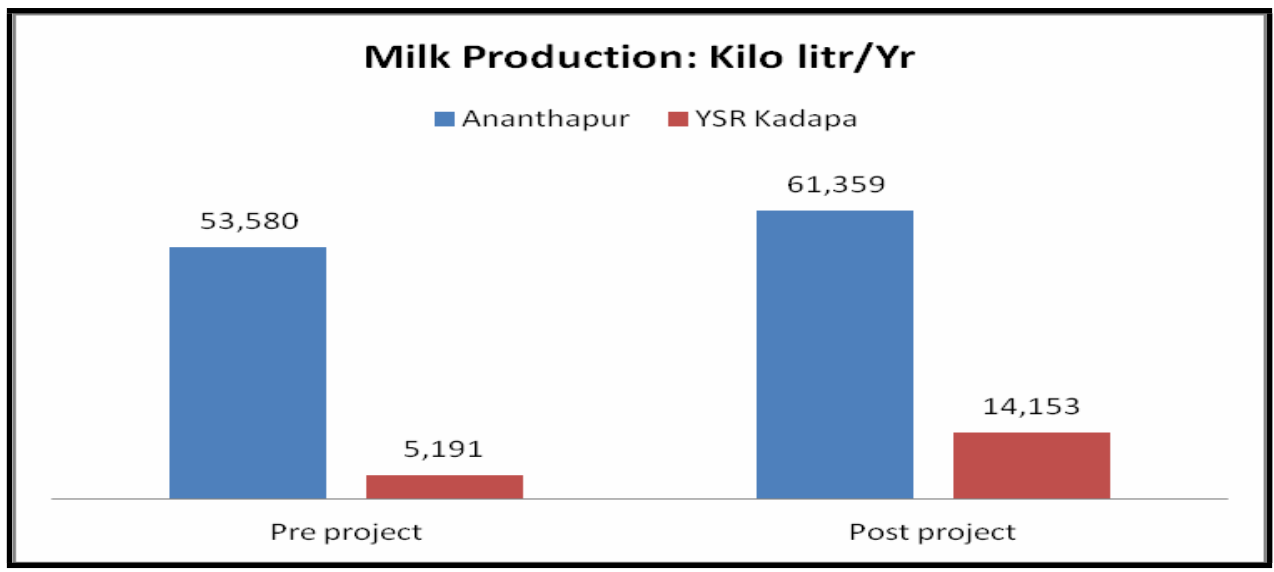

Fig.4

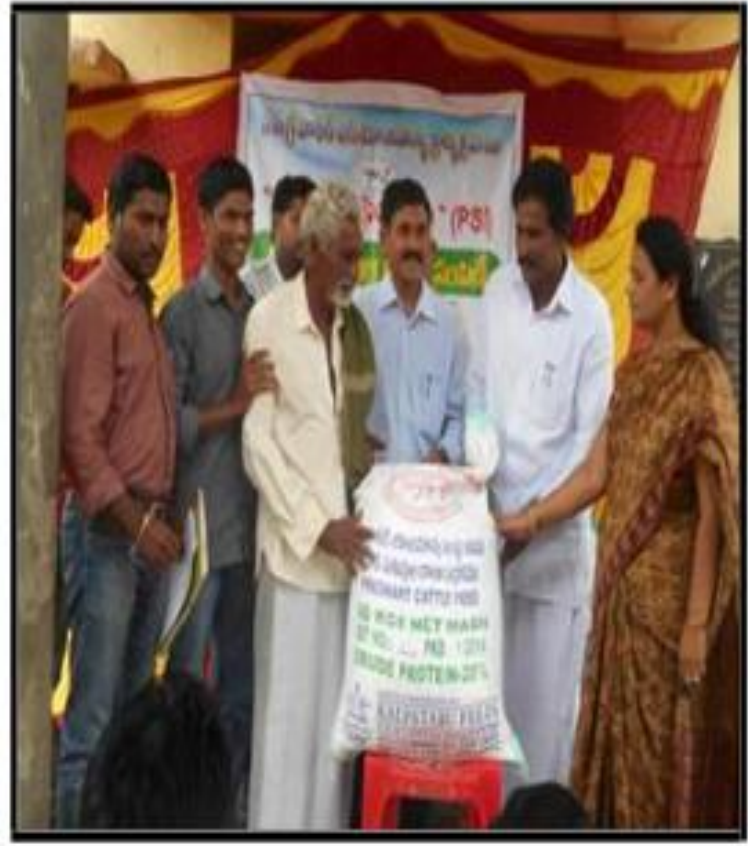

In general, effect of watershed programs on animal husbandry indicates that livestock holding potential in watershed areas has improved due to watershed development programs, although some improvements have been made.

The composition of the animals has undergone a change; firstly, the local variety of cows, buffaloes have been replaced by crossbreed cows, buffaloes; and secondly, the

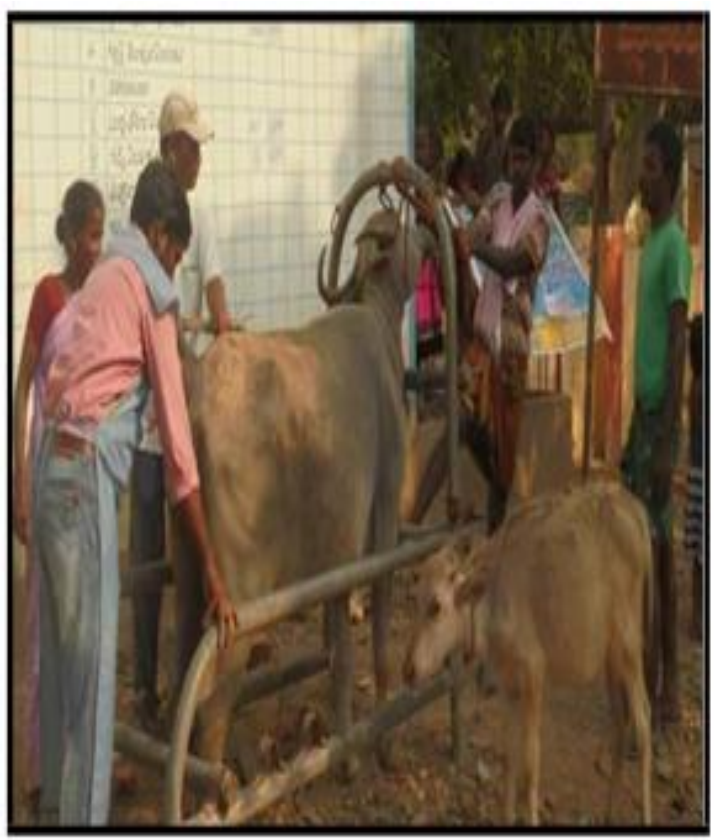

number of milch animals and small ruminants have increased such as sheep and goats. The dairy operation is gaining importance in the watershed areas due to the availability of feed and other related facilities such as the availability of artificial insemination services and so on. It is also noted that the number of farmers engaged in dairy farming has increased thus milk production. 
Number of farmers engaged in dairy farming has increased and milk production has also increased accordingly. As far as feeding practices are concerned, the major change recorded is that usage of mineral mixture along with green fodder has increased. The watershed programme provided mineral mixture to the livestock which helped animal's nutrition and resulted more milk production.

As concerned with the livestock production, watershed programme also established travices, water trough facilities etc., all these directly or indirectly helped the animal development in the watershed villages. There is a close linkage between the various aspects of farm-based activities and livestock sector especially green fodder availability, feed availability, and animal health. The livestock sector makes a significant contribution to the income in the watershed villages with welldeveloped dairy sector.

Success of the dairy sector depends on several aspects as mentioned above and the Impact of watershed village indicates that due to implementation of watershed program the availability of feeds and fodder increases for instance, green fodder has stimulated the growth of dairy sector. At the same time, different interventions in the livestock management in watershed villages clearly indicated the watershed program is beneficial to landless poor, small and marginal farmers in the selected watershed villages.

\section{References}

\section{How to cite this article:}

Reddy, P. V. R. M., B. V. Ramana Kumar, R. Jhansi Rani and Pullanna Vidyapogu. 2021. A Holistic Approach in Enhancing the Livestock Production in Drought-hit Watersheds: Case Studies of Ananthapuramu and YSR Kadapa Districts of Andhra Pradesh, India. Int.J.Curr.Microbiol.App.Sci. 10(05): 661-671. doi: https://doi.org/10.20546/ijcmas.2021.1005.074
National Rainfed Area Authority. "Common Guidelines for Watershed Development Projects- 2008 Revised Edition- 2011." (2011).

Arya, Swarn Lata, Pankaj Panwar, and R. P. Yadav. "Role of watershed management in bridging demandsupply gap of fodder for enhancing livestock production in Shivaliks, Haryana." Agricultural Economics Research Review 24, no. 347-201616956 (2011): 225-234.

Puskur, Ranjitha, Jetske Bouma, and Christopher Scott. "Sustainable livestock production in semi- arid watersheds." Economic and Political weekly (2004): 3477-3483.

Pathak, Prabhakar, Anil Kumar Chourasia, Suhas P. Wani, and Raghavendra Sudi. "Multiple impact of integrated watershed management in low rainfall semi-arid region: A case study from eastern Rajasthan, India." Journal of Water Resource and Protection 5, no. 1 (2013): 27-36.

Gregersen, Hans M., Peter F. Ffolliott, and Kenneth N. Brooks, eds. Integrated watershed management: Connecting people to their land and water. CABI, 2007.

Palsaniya, D. R., Ramesh Singh, R. K. Tewari, R. S. Yadav, and S. K. Dhyani. "Integrated watershed management for natural resource conservation and livelihood security in semi-arid tropics of India." Indian Journal of Agricultural Sciences 82, no. 3 (2012): 241. 